\title{
The Impact of International Integration on the Inequality of Income between Rural and Urban Areas in Vietnam
}

\author{
Thi Thanh Huyen NGUYEN*, Thi Thu Hien NGUYEN**, Thi Le Hang NGUYEN ${ }^{* * * *}$, Van Cong NGUYEN**** \\ Received: January 28, 2020 Revised: February 9, 2020 Accepted: February 11, 2020.
}

\begin{abstract}
The study examines the impact of international integration on Vietnam's rural and urban income inequalities using the regression model. The data used for this study is based on the results of the Vietnam Household Living Standards survey from 2008 to 2016 of the General Statistics Office. These surveys conducted nationwide with a sample size of 46,995 households in 3,133 communes/wards which were representative at national, regional, urban, rural and provincial levels. The level of international economic integration used in the study is the proportion of import and export turnover of GDP, the proportion of FDI and GDP by province. Due to the heterogeneity and unobservableness of the single observant in the data set, we selected the models of random and fixed effects. The research results show that during the economic integration process, the Export/GDP factor is negatively related to income inequality. The remaining factors (GDP per capita, FDI/GDP, Educational level of households, Percentage of internet users, Aggregation of foreign cash inflow and GDP of the province) are all positively related to income inequality. The findings help assess the impact of international integration on rural-urban income inequality, but also provides a concrete basis to help policymakers address income inequality in the integration process.
\end{abstract}

Keywords: Income Inequality, International Integration, Rural, Urban, Vietnam

JEL Classification Code: F60, F61, F62, F63

\section{Introduction}

Recognizing the importance of equality in socioeconomic development, the Government of Vietnam has given priority to this issue early (Communist Party of Vietnam, 1987). Economic growth and societal fairness become the major principle for the country's leadership and administrate the economy. This ideology was emphasized as follows: ideology was emphasized as follows: (1) The

${ }^{*}$ First Author. Faculty of Environmental, Climate Change and Urban Studies, the National Economics University (NEU), Vietnam. Email: huyennt@neu.edu.vn

${ }^{* *}$ Faculty of Industrial University of Ho Chi Minh City (IUH), Hochiminh City, Vietnam. Email: nguyenthuhien@iuh.edu.vn

***Faculty of Economics and Accounting, Quy Nhon University, Quy Nhon, Vietnam. Email: ntlhang@qnu.edu.vn

${ }^{* * \star *}$ Corresponding Author. Professor, School of Accounting and Auditing, The National Economics University (NEU), Vietnam. [Postal Address: 207 Giai Phong, Dong Tam, Hai Ba Trung, Hanoi, 113068, Vietnam] Email: anhcongtuan@gmail.com

(c) Copyright: The Author(s)

This is an Open Access article distributed under the terms of the Creative Commons Attribution NonCommercial License (https://creativecommons.org/licenses/by-nc/4.0/) which permits unrestricted noncommercial use, distribution, and reproduction in any medium, provided the original work is properly cited. economic growth and social equality must go hand in hand in the entire process of development, (2) Citizens are equally treated in the opportunities of development as well as the demonstration of their capabilities, (3) The development gap in geography, ethics and social levels must be considered and gradually narrowed (Communist Party of Vietnam, 2011, 2016). However, as a matter of fact, the link between the economic growth and social equality has been controversially proven over the past two decades as Gini, a crucial indicator reflecting this relationship, was on the upward trend from 0.32 in 1993 to 0.424 in 2018 (General Statistics Office, 2018). This increasing gap is deemed to the rising discrepancy in income and poverty. In Vietnam, impressive economic growth in recent years has helped to significantly reduce poverty rates across the country. However, inequality or the gap between rich and poor is rapidly increasing in society between urban and rural areas, between ethnic minorities and the majority, between economic sectors.

From in 2006, Vietnam has become a full member of the World Trade Organization (WTO). This milestone has brought many innovations to Vietnam's economy but as a 
rule of thumbs, opportunity and challenge always go hand in hand. Vietnam is supposed to take advantage of low-cost labour to enhance its competitiveness and materializing it into positive factors with an aim to neutralize the inequality. However, failing to do so would make it possible for Vietnam to worsen the current situation of social inequality. It is important that the Government needs to be consistent with the early established principle in its macro-economic administration in a way that international economic integration brings positive effects on the development of the whole country without enlarging the gap between the rich and the poor within societies.

From that, the question is asked: What are we supposed to do and how to do in order for the process of integration into the world economy not to adversely affect the inequality of our society?. And this is also the research question of this article when it comes to the empirical study of the intermediaries through which international integration of the economy can have an impact on income inequality.

This study aims to examine and formulate strategic responses to the impacts of international economic integration on income inequality between rural and urban areas of Vietnam. The proposed policy decision combined with the macroeconomic governance policies of the Government of Vietnam is expected to be made as a guide for the integration process. In this study, the research questions are: (1) How do we consider the impact and causes of economic integration on rural-urban economic inequality in Vietnam? (2) Trends of the impact of international integration on income inequality, and (3) What policies should be applied to narrow the income inequality gap in the process of economic integration?

\section{Literature Review}

Researches on the impact of economic integration on income inequality have been well researched in the world as well as in Vietnam. The conclusions show empirical evidence of the close relationship between these two factors. However, the conclusions from these studies only give a warning about the change in income inequality in the process of economic integration on a macro scale, without giving any explanation from social. Economic integration affects inequality across channels. Therefore, there are no solutions in reducing the level of inequality in the trend of international economic integration.

Among the many studies on inequality between rural and urban areas, conducted on an international and local level, is highlighted by Mundle and Arkadie (1997). The authors researched and analyzed the income and expenditure disagreements between rural and urban areas from 1993 to 1998 and came to the conclusion that there is an income gap between the two areas. Based on the analytical model on the differentials developed by Blinder Oaxaca (Blinder, 1973; Oaxaca, 1973), they proved that the gap of income among 02 groups of people living in rural and urban areas is well explained by such attributes as education, ethics and professionals. Especially, by using quantitative analysis, the authors examined the role of the Government in this inequality. In addition, there are other studies on this subject, but none consider the factor of international integration.

There are many qualitative and quantitative studies on the impact of international integration on national economies. The standard economic theory of international trade has provided a model for assessing changes in income distribution due to trade development. In the simplest framework, the more abundant the factors of production, the greater the demand for them and the relative income they bring (Stolper \& Samuelson, 1941; Neary, 2004) along with the increase in trade. For a developing country with an abundance of unskilled labor (but few skilled workers), two phenomena are simultaneously observed: reducing inequality and reducing poverty (level of inequality). Within the intra-group between the families of skilled workers and the families of unskilled workers has not changed significantly). Simulations of the impact of trade liberalization on income distribution have been made based on the computable general equilibrium models (CGE) that yield relatively conflicting results. In the case of South Africa, trade liberalization harmed the poor in the short term but has a positive long term impact (Mabugu \& Chitiga, 2007).

Araujo, Ferreira, Lanjouw, and Lanjouw (2008) showed that the poorer the locality, the more support it will receive from the project if the income distribution in that locality is relatively equal and vice versa. The study generally analyzes how poor people receive support from projects. Goesling and Baker (2008) analyzed the trend of the three main inequality issues in the world today, which are income, health and education inequality. Research analyzing data of more than 100 countries in the world shows that income inequality tends to decrease. However, the trends of inequality in education and health are increasing.

Perry and Olarreaga (2006) have shown that trade liberalization in the 1990s in Latin America was a reduction in the wages of low-skilled workers and an increase in wages of highly-skilled workers, which contributes to an increase in the level of income inequality. The authors analyzed that the main causes of a relative change in the aforementioned salary include: (1) In the years 1990 when Latin American countries integrated into the world economy, the countries owned large numbers of 
poor labor and as low as China and India had been in preintegration, and these Latin American countries became water-advantage resources instead of the low-level labor advantage. (2) Barriers before the integration of these countries were protection for low-level labor, so removing this barrier did not give benefits to this type of laborer. (3) The development of the production sector due to trade liberality had made the bridge increase to the skilled labor market, with which the development of the technology made the labor market growth in a beneficial way for the workers highly-available. However, after the year 1990, these countries after strong reductions in import and export tariffs have witnessed an increase in income inequality.

Another study, using statistical analysis for Mehico (Estrada, 2008) also concluded that the same conclusion of international economic integration in the country increased the level of income inequality. Wei and Wu (2001) indicated a counter-dimensional relationship between rural and urban inequality in Chinese cities with an economic opening. Which province had a greater increase in the trade/GDP ratio, there was a faster reduction than RuralUrban colleges. This study established the estimated regression model of the province by the provincial, the proportion of trade measured by import-export and the unequal index of rural income-urban measures measured by the difference in income of rural-urban households. However, Tian, Wang, and Dayanandan (2008) researching the relationship between international economic integration and inequality in income in China, it is found that international economic integration helps to alleviate the level of inequality in household income This country. In this work, the authors used a dynamic model consisting of Tier 1 integrated copper variables, in which the explanatory variables include: GDP per capita growth, the ratio of import and export turnover to GDP, the ratio between FDI and GDP-these two variables for economic integration, and the level of government expenditures for social security. The estimate suggests that economic integration is not the cause of an increase in the level of inequality in the country's income, but rather by other causes.

Bukhari and Munir (2016) mentioned the impact of globalization on income inequality in selected Asian Countries, include Bangladesh, China, India, Indonesia, Malaysia, Pakistan, Philippines, Sri Lanka, Singapore, South Korea and Thailand. The study used panel data for selected Asian countries from 1980 to 2014 for trade and technological globalization model and from 1990 to 2014 for financial globalization model. Results show that trade and technological globalization in the selected Asian economies significantly contributes to reducing income inequality while financial globalization increases income inequality. Education has inverse impact on income inequality while foreign direct investment has positive relationship with income inequality. Atif, Srivastav, Sauytbekova, and Arachchige (2012) studied the causal effect of globalisation on income inequality by estimating static and dynamic models for panel data of 68 developing countries over the period of 1990-2010. The results confirm that an increase in globalisation in developing countries leads to an increase in the level of income inequality. Regarding the spatial distribution of economic growth and inequality, Nurlanova, Satybaldin, Bekturganova, and Kireyeva (2018) conclude that the main direction of regional policy is to find and develop "the growth poles", where will distribute their potential equally to backward regions of Kazakhstan. The results of the study have demonstrated that there is a spatial difference in economic development, but its degree and motivation vary in different aspects.

Recently, a number of studies have mentioned the indirect effects of globalization on economic growth, thereby affecting income inequality or the impact of income inequality on economic growth. Research by Majumdar and Partridge (Majumdar \& Partridge, 2009) on the impact of economic growth on income inequality between urban and non-urban areas (district level) in the 1990s and 2000 with data collected from the Ministry US census. Research results show that: Economic growth has a negative impact on income inequality because economic growth is often positive in relation to higher investment, higher job creation and higher employment, as that has more access to employment and more income for people. However, growth can reduce income inequality in urban areas because higher population densities lead to more personal contacts, better connections and access to information, so there are more opportunities to access better jobs. Joshi's study (Joshi, 2018) assessing the impact of income inequality on economic growth of Indian states shows a strong significant positive impact on the existence of inequality. The growth of Indian states, if anything, statistically confirms the existence of tradeoffs between the two sides.

Research on the impact of income inequality, land and assets on agricultural expansion in Latin America through studying the relationship between different types of inequalities (especially income, wealth, and land concentration), agricultural intensification, and agricultural expansion in Latin America, Ceddia (2019) points to an increase in inequality in all its forms, promoting agricultural expansion. Thus eroding the land-sparing effects of increasing productivity. At the same time, his research also shows that the immediate effect of inequality is greater than the overall effect (accounting for temporal lags) and that the effects of income inequality are stronger than those of land and wealth inequality, respectively. When studying the urban-rural gap and poverty traps in 
China, $\mathrm{Wu}$, and $\mathrm{He}$ (2018) examines the dynamic behaviors of incomes for both urban and rural areas with a prefectural data set by the analysis is conducted by using a distribution dynamics approach. The results show that persistence and immobility are the dominant characteristics in the income distribution dynamics. Examination on the dynamics of the poorest areas shows that geographical poverty traps exist in both urban and rural prefectural areas.

Research on an effect of internet penetration on income inequality in Southeast Asian Countries, Ningsih and Choi (2018) conducted to examine determinants of income inequality in Southeast Asian countries (technological change, globalization and tax policy on income inequality) by using panel regression analysis. His study shows that internet penetration as a proxy of technological change has reduced income inequality significantly, tax revenue to GDP ratio has also reduced income inequality, but the effect is not significant. Globalization measured by FDI and trade to GDP ratio has increased income inequality, although FDI impact is not significant. Lee and Brahmasrene (2016) address the tourism impact on the environment and economic sustainability of sub-Saharan Africa in a multivariate format using the unified regression model and the regression table (Lee \& Brahmasrene, 2016). Another study on contribution of tourism receipts and foreign direct investment to Gross Domestic Product (GDP) of Sri Lanka by Mustafa Mohamed (2019) based on annual data on time series for the period from 1978 to 2016 showed a positive and statistically significant relationship between foreign direct investment and tourism receipts and GDP long term.

For the impact of foreign direct investment and human capital on labor productivity, Le, Duy, and Ngoc (2019) provided strong statistical evidence that foreign direct investment and human capital had a positive effect on longterm labor productivity in Vietnam. These findings imply that workers are expected to further improve their knowledge, skills, and policy-makers should set specific plans to increase human capital. The results of this study provide the necessary hints for Vietnam to achieve sustainable development. Nantharath and Kang (2019) considered the impact of foreign direct investment on the economic growth of the Lao People's Democratic Republic from 1993 to 2015 based on the impact of growth and economic absorptive capability determinants such as human capital, trade openness, and institutional quality. The research results demonstrate the positive effects of foreign direct investment and trade openness, and the negative effects of human capital and institutional quality on economic growth. The findings of the study also confirm that trade openness is complemented by a sufficient level of infrastructure, education, quality institutions, and transparency significantly influence economic growth and attract more foreign direct investment.

In Vietnam, some authors have also researched this issue, such as Roland-Holst and Tarp (2003) who used computable general equilibrium model (CGE) and used the VLSS metric 1998 and SAM panel 2000 to estimate the impact of the integration of Inequality between rural areas and urban areas. The authors concluded that the reduction of some import and export duties did increase the number of poor people in rural areas and the increase was faster than the urban area. Along with the use of a dynamic computable general equilibrium model (DCGE), Nguyen (2011)has calculated the effect of Vietnam joining WTO to distribute income and welfare among five groups of households in Vietnam. Analyzing the possible impacts of WTO entry up distribution of income and the poor gap between the household groups has provided a real witness result that farmers (farming workers) are likely subjects in the process of integration of the country. In general, the author's conclusion is the impact analysis primarily attributed to the tariff policy, other factors such as importexport operations, foreign investment. Authors have not included in the analysis as well as the internal factors of households such as education, careers...

Trinh and Nguyen (2008) mentioned a poor social stratification, affirming the increase in general inequality phase 1993 to 2004 mainly. They showed that the increase in inequality between urban-rural areas and internal inequality, and affirmed the phenomenon of inequality in Vietnam is subjected to the direct impact of international integration and foreign direct investment. However, the authors do not give a measurement of international integration and with foreign direct investment (FDI). Recently Nguyen (2009) has calculated the inequality index in 64 provinces for the year 2002, 2004, 2006 using the residential Living level survey the respective years. She used the GINI coefficient to measure the inequality index and to make estimates of technical efficiencies, technological changes for the provinces in 3 years respectively. She also to build and estimate the economic model of energy using the impact assessment of international economic integration, and to use the Tobit model to evaluate the impact of technical performance factors, technological advances, and labor productivity to the level of inequality in income between households. The results show that international economic integration has had a positive impact on the underlying elements of the production and that the fundamental factors in production have a contrast correlation with the level of inequality in income. However, the author analyzes the facet of households rather than analyzing the difference between rural and urban.

In general, the research results show that the impact of 
international economic integration on inequality in earnings in an economy is not only dependent on the relative level of comparison of resources in that economy in relation to the background the world economy but also depends on many other factors, such as the nature of barriers to international trade before integration, on the level of development of the world economy as well as of the economy under consideration. From 2002 onwards, Vietnam has been experiencing large steps in the process of international economic integration. The nature of Vietnam's economy has also made fundamental changes, in which the private sector has evolved, the economy in general and individuals, in particular, have also become more active and more responsive to the changes and external impacts. Nevertheless, whether every class in society qualifies and can access development opportunities provided by the integration is still controversial.

Vietnam is now still an agricultural country with about
$70 \%$ of social workers living by farming. As the number of skilled and high-level workers living in the urban area benefited greatly while the farmer suffered a lot of risks from the process of integration of the country will cause the poor disparity of the urban and rural areas on a Wide. Besides, in urban areas, the majority of the poor now do the job with low wages, conditions of work deprivation, unstable, ... The question is: whether the process of the international economic integration of Vietnam creates the potential risk for increasing the level of inequality in households living in rural and urban areas, as well as between households living in urban and living in rural areas? The prediction and analysis of the possible impacts of international integration on the inequality of income between rural and urban areas are essential for thereby the State has policies that support the subject to lose this loss.

The impact of international integration on rural-urban inequality can be generalized in Figure 1.

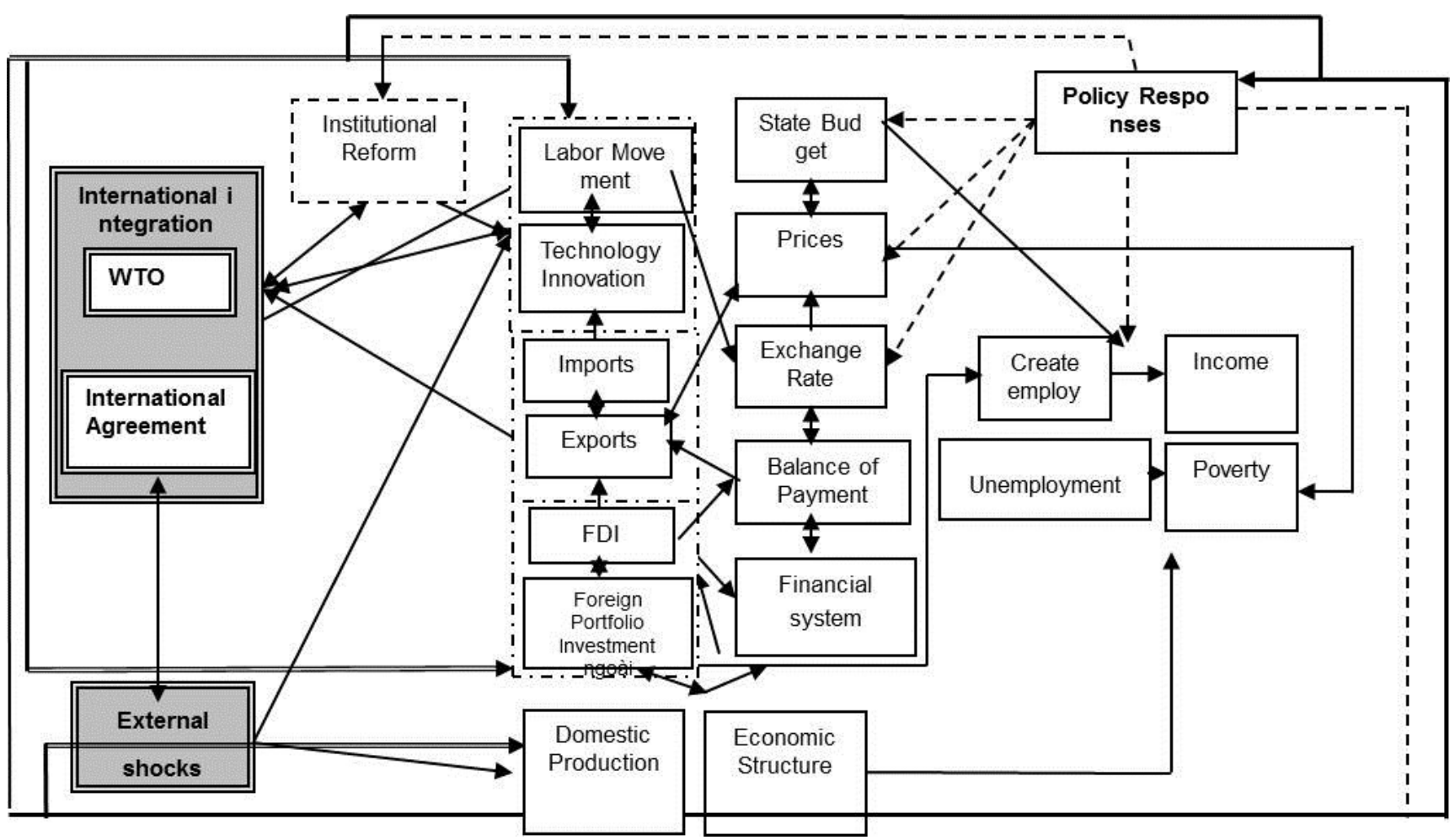

Figure 1: Analytical framework assesses the impacts of international integration on the income inequality Source: Central Institude for Economic Management (2010) and authors' expansion

\section{Research Methods}

\subsection{Measures of the Inequality}

Inequality can be measured in one of the following ways: (1) The group approach - the entire population is divided into 05 groups having the similar size with the ascending rating of income (poor, near-poor, medium, fair, and rich groups), then the distribution of the total income is estimated to each group, (2) The alternative approach of Lorenz curve. This curve demonstrates the correlation between the highest income group and the lowest income group. The gap between the Lorenz curve and the diagonal 
line reflects the degree of the inequality, the larger the gap, the higher the inequality. GINI coefficient is calculated based on Lorenz curve, the most frequently used approach to the inequality. GINI coefficient has a range of values between 0 and 1 where 0 refers to complete equality and 1 refers to the incomplete inequality, or also between $0 \%$ and $100 \%$ if measured in percentage, (3) The approach of Theil indicator. Theil is an advanced approach of GINI coefficient. While GINI coefficient is only applicable to calculate the separate inequality of various areas such as the entire country, the urban and the rural and fails to demonstrate the detailed difference between the urban and the rural in association with 03 different levels: country, areas and provinces.

Theil (T) formula is seen as follows (Subramanian, 1997):

$\operatorname{Theil}(T)=\sum_{i=1}^{N} \frac{Y i}{Y} \ln \left(\frac{Y i N}{Y}\right)=\sum_{j}\left(\frac{Y j}{Y}\right) T j+\sum_{j} \frac{Y j}{Y}\left(\frac{Y j / Y}{N j / N}\right)$

where:

Y: The aggregate income or spending of the entire population

Yi: The sum of income or spending of the observed $i$.

$\mathrm{N}$ : The total number of people

Yj: The sum of income or spending of the observed $j$

$\mathrm{Nj}$ : The number of people in group $\mathrm{j}$

$\mathrm{Tj}$ : The measure of the inequality of income or spending in group $\mathrm{j}$.

\subsection{Research Data}

The data used for this study is based on the results of the Vietnam Household Living Standards survey from 2008 to 2016 of the General Statistics Office. To evaluate living standards for policy-making and socio-economic development planning, from 1993 to now the General Statistics Office conducts the Viet Nam Household Living Standards Survey (VHLSS). The purpose of the VHLSS in order to systematically monitor and supervise the living standards of different population groups in Viet Nam; to monitor and evaluate the implementation of the Comprehensive Poverty Reduction and Growth Strategy; and to contribute to the evaluation of achievement of the Millennium Development Goals (MDGs), Sustainable Development Goals (SDGs) and Vietnam's socio-economic development goals. The VHLSS 2016 was conducted nationwide with a sample size of 46,995 households in 3,133 communes/wards which were representative at national, regional, urban, rural and provincial levels. The survey through face-to-face interviews conducted by interviewers with household heads and key commune officials in communes containing sample enumeration areas (General Statistics Office, 2016).

We believe that the use of research data is based on data released by the General Statistics Office of Vietnam and the period from 2008 to 2016 to study the impact of economic integration on income inequality is absolutely correct for the following reasons:

Residential life and social security: Overall, the poverty rate in Vietnam dropped significantly during 2012-2016. The multidimensional poverty rate decreased from $18.1 \%$ to $10.9 \%$ during this period. The expenditure poverty rate decreased from $17.2 \%$ to $9.8 \%$, while the income poverty rate decreased from $12.6 \%$ to $7.0 \%$. In addition, social security continues to be paid attention to. According to the preliminary report, the total expenditure for social security and poverty reduction in 2016 was VND 7303 billion and more than 18.3 million health insurance, free health care books/cards were donated. for policy beneficiaries across the country (Ministry of Labor - Invalids and Social Affairs, 2018).

Economic growth rate: After 10 years of joining the WTO (2007 - 2016), despite the impact of the global financial crisis and public debt crisis, Vietnam has maintained a series of economic growth. The average economic growth rate in 10 years of Vietnam was $6.29 \%$. Average GDP reached 1,600 USD per capita, people's living standards have improved. Vietnam from a low per capita income country since 2008 has become a middleincome country in 2016. The economic structure at current prices has shifted in a positive direction, in line with requirements of development. This is a very important economic achievement in the context of very difficult natural disasters, epidemics, fluctuations in world prices and the global economic crisis (General Statistics Office, 2017).

Regarding the import-export situation: By the end of 2016, the total import-export turnover of the country reached more than 350.74 billion USD, up $7.1 \%$, equivalent to an increase of nearly 23.16 billion USD over the same period last year. In particular, exports reached more than 176.63 billion USD, up 9\%, equivalent to an increase of nearly 14.62 billion USD; import reached more than 174.11 billion USD, up $5.2 \%$, equivalent to an increase of over 8.54 billion USD (General Department of Vietnam Customs, 2017).

\subsection{An Empirical Research Model}

The level of international economic integration used in the study is the proportion of import and export turnover of GDP, the proportion of FDI (capital executed) and GDP by province. There are 03 common models used to analyze cluster data. They are the accumulative squared model (POL), random effects and fixed effects. Due to the heterogeneity and unobservableness of the single observant in the data set, we selected the models of random and fixed 
effects. The model of random effects is a model in which heterogeneous and unobservable variables are noncorrelated to the independent variables of the model. The model of fixed effects is a model in which heterogeneous variables are correlated to the independent variables of the model, then the accumulation of these heterogeneous variables into random errors of the model, which is analogous to the model of random effects.

Inspired by the idea of Kuznets (1955) and the extension of Panizza (2002) on the link between the growth and regional discrepancy in association with other studies of Nguyen (2009), the authors of this research establishes an analytical model to the impacts of the international integration on rural-urban inequality as follows:

Theilij $=\beta 0+\beta 1$ XKij/GDPij $+\beta 2$ LnGDPbqij + $\beta 3$ FDIij/GDPij $+\beta 4$ Edu0ij $+\beta 5$ Edu3ij $+\beta 6$ TLij $+\beta 7$ LogTGNNij $+\beta 8 \operatorname{LogGDPij}+\varepsilon i j$

The variables in the model are shown in Table 1.

Table 1: Explanation of variables in the model

\begin{tabular}{|c|c|}
\hline Theil $_{\mathrm{ij}}$ & $\begin{array}{l}\text { Theil index is indicative of the inequality in the rural- } \\
\text { urban province (i) in the year (j). }\end{array}$ \\
\hline$\beta_{0}, \beta_{1, \ldots,} \beta_{8}$ & Correlation coefficients \\
\hline $\begin{array}{c}\mathrm{XK}_{\mathrm{ij}} \\
/ \mathrm{GDP}_{\mathrm{ij}} \\
\end{array}$ & $\begin{array}{l}\text { Export Value of province (i) in the year (j) to GDP } \\
\text { (quoted to the comparative price in million VND) }\end{array}$ \\
\hline $\begin{array}{c}\log G D P b \\
q_{i j}\end{array}$ & $\begin{array}{l}\text { Logarite GDP per capita quoted to the comparative price } \\
\text { of province (i) in year (j). }\end{array}$ \\
\hline$\underset{\substack{\mathrm{Fij} \\
\mathrm{Fij}}}{\mathrm{in} / \mathrm{GDP}}$ & $\begin{array}{l}\text { The implemented FDI to GDP quoted to the comparative } \\
\text { price of province (i) in year (j). }\end{array}$ \\
\hline $\begin{array}{l}E d u 0_{i j} \\
E d u 3_{i j}\end{array}$ & $\begin{array}{l}\text { The educational level of households (the number of } \\
\text { household owners without going to schools or having the } \\
\text { high school's certificate in rural and urban areas) in } \\
\text { province (i) and year (j) }\end{array}$ \\
\hline $\mathrm{TL}_{\mathrm{ij}}$ & $\begin{array}{l}\text { The percentage of internet users in province (i) and year } \\
\text { (j). }\end{array}$ \\
\hline $\begin{array}{l}\log \text { TGN } \\
\mathrm{N}_{\mathrm{ij}}\end{array}$ & $\begin{array}{c}\text { Logarite the aggregation of foreign cash inflow into } \\
\text { province (i) and year (j) as a representative of foreign } \\
\text { workers in province (i) }\end{array}$ \\
\hline $\operatorname{LogGDP}$ & $\begin{array}{l}\text { Logarite GDP quoted to the comparative price of } \\
\text { province (i) in year (j). }\end{array}$ \\
\hline$\varepsilon_{\mathrm{ij}}$ & Random variance \\
\hline
\end{tabular}

Source: Compiled by the authors based on research results

\section{Results and Discussion}

Table 2 displays that most variables in the model are closely related to the inequality of rural-urban income in the 2008-2016 period. Concretely, the Export to GDP (XK/GDP) variable has a close relationship with the inequality of rural-urban income with a statistical significance of $10 \%$. The negative coefficient implies that the province has a high volume of exported commodities is associated with a lower level at the inequality of income and this is reasonable to Vietnam whose exported goods are mainly farming products, textile and garments with an intensity of labor. For example, the structure of export turnover in 2016 of Vietnam changed insignificantly compared to 2015 , in which heavy industry and mineral goods gained 79.8 billion USD, up $8.9 \%$ and accounted for $45.4 \%$ of the total needle. export turnover (increasing by 0.1 percentage points compared to 2015); the group of light industry and handicrafts reached USD 71 billion, up 9\% and accounting for $40.4 \%$ (up 0.2 percentage points); agricultural and forestry products reached USD 18.1 billion, up $6.5 \%$ and accounting for $10.3 \%$ (down 0.2 percentage points); fishery products were estimated at 7 billion USD, up $6.8 \%$ and accounting for $4 \%$ (down 0.1 percentage point).

Export turnover of 10 major commodity groups in 2016 reached nearly 126.85 billion USD, accounting for $71.8 \%$ of the country's total export turnover. In particular, the largest is phones and phone components accounted for $27.1 \%$; textile and garment $18.8 \%$; computers, electronic products and components $14.9 \%$; footwear $10.2 \%$; machinery, equipment, tools and other spare parts $8.0 \%$; aquatic products $5.6 \%$; wood and wood products $5.5 \%$; means of transportation and spare parts $4.8 \%$; coffee $2.6 \%$; bags, wallets, suitcases, hats, umbrellas $2.5 \%$. Vietnam's export commodities are mostly traditional goods, which require little capital but use more employers (the laborintensive sector). This makes use of Vietnam's commercial advantage, thereby leading to an increase in income for workers, especially rural people, increasing exports, reducing the gap between urban and rural. These changes are absolutely suitable, especially in the context of Vietnam in recent years (General Department of Vietnam Customs, 2017).

Table 2: Results of regressive model 1 (fixed and random effects)

\begin{tabular}{|c|c|c|c|c|}
\hline Variable & \multicolumn{2}{|c|}{ Fixed effect } & \multicolumn{2}{c|}{ Random effect } \\
\hline $\begin{array}{c}\text { Theil }(\mathrm{T} \\
\text { dependent } \\
\text { variable) }\end{array}$ & Coef & $\mathrm{P}>|\mathrm{t}|$ & Coef & $\mathrm{P}>|\mathrm{t}|$ \\
\hline $\mathrm{XK} / \mathrm{GDP}$ & -0.0082 & $0.097^{*}$ & -0.0041 & 0.405 \\
\hline LogGDPbq & 0.0278 & $0.002^{*}$ & 0.0256 & 0.001 \\
\hline TL & 1.2225 & $0.000^{*}$ & 1.0768 & 0.000 \\
\hline FDI/GDP & 0.0585 & $0.003^{*}$ & 0.0265 & 0.306 \\
\hline Edu3 & .0007 & $0.100^{*}$ & -0.0002 & 0.439 \\
\hline cons & -.0587 & $0.020^{*}$ & -0.0138 & 0.434 \\
\hline
\end{tabular}

Source: Compiled by the authors based on research results

On the other hand, this conclusion also matches the new Heckscher-Ohlin (Leamer, 1995) neoclassical model theory and the Stolp-Samuelson theorem (Stolper \& Samuelson, 1941) that argues that trade liberties will help 
reduce inequality in developing countries due to an improvement in the relative advantages of low labor level, and some experimental studies by some other authors specifically a study of the Vietnamese author Nguyen (2011) he believed that under the impact of joining the World Trade (WTO), the production value of the country over the long term will increase to 53,392 billion, corresponding to an increase of $4.66 \%$ over the original year. The seafood processing industry has the fastest rising rate of $52.97 \%$. The catch and aquaculture industry also has a fast pace $(22.72 \%)$.

As the strength of Vietnam's economy is the ocean economy, it is possible to realize that the WTO's entry will have a positive impact on the fisheries processing industry and the most pronounced cultivation. The extraction industries, manufacturing of spare parts, textiles, leather shoes, trade, and transportation are the ones that have the advantages to develop. The production value of these disciplines is predicted to grow considerably in the long term. The manufacturing industry of motorcycle cars, manufacturing industry, and a number of service sectors may be faced with many difficulties.

When labor-intensive industries have the opportunity to grow rapidly and expand investment, production and export scale, there will be an increase in demand for all types of labor and therefore the salary of the workers is predicted to increase. Due to the expansion of fisheries and mining sectors, the demand for the male economy in rural development grew rapidly, leading to the salary of this type of labor to increase at most. For other types of labor, the rural salary increase is lower than the urban. The salary of the female labor skilled in urban prediction rapidly increases. Due to the rapid development of the manufacturing and processing industries, many women's workers such as seafood processing, textiles, leather shoes, and trade. The increase in the salary of all types of labor at different speeds will directly impact the income from the labor of the household groups. However, rural households receive a significant improvement in labor income faster than household groups in the urban.

Tian, Wang, and Dayanandan (2008), when studying the relationship between international economic integration and inequality in income in China, it was found that international economic integration helped to alleviate the level of inequality in the income of these country households, or Wei and Wu (2001) also confirmed the opening of the economy (specific measurement by export/GDP) also has a reverse relationship Between international integration with inequality of household income, or author Nguyen (2009) also pointed out that the integration treatise has a positive impact on the income inequality among households in Vietnam. However, there are also some other contrary conclusions such as Perry and
Olarreaga (2006) which have pointed out that trade liberations during the 1990 years in Latin America have been a decrease in wages by low-level workers and the increase of wages by workers high level of activity, thus contributing to increased levels of inequality in income. But overall, the estimated outcome of the model of the relationship between urban-rural income inequality and export/GDP is perfectly suited to reality.

LogGDPbq shows a strong positive relationship with the inequality in that the higher the growth rate of GDP, the higher the inequality of rural-urban income. This can be quite appropriate to what is happening in Vietnam where urban citizens take advantage of earning more than people living in rural. If a review of previous research in theory as well as empirical the relationship between economic growth and income inequality, there are also similar conclusions, namely Forbes (2000) research in specific countries with the use of Whether the plate and the model estimate the fixed impact, more and more growth conclusions are also drawn under incremental income inequality, or Barro (2000) Researching this relationship in two extremes, one is the developing world and one is developed by the country, for two different conclusions, in developed countries, the relationship between growth and inequality is positive, while developing countries are negative (in contrast).

TL variable is positive relative to the inequality of income with a significance of $5 \%$ in statistics. This close relationship indicates if the proportion of households using the Internet is higher, the greater the inequality, this also perfectly fits the theory as well as the experiments, because households with conditions of Internet use are relatively high-income households, which are concentrated in the urban area.

FDI/GDP has a positive relationship with the inequality of rural-urban income with having a statistical significance of $5 \%$, meaning that the more Vietnam attracts investment capital from foreigners, the bigger the gap of income between rural and urban areas will be. As a matter of fact that FDI distribution in Vietnam resides principally in provinces of good infrastructures. This means that as much as foreign direct investment, the more the increase in rural and urban income inequality. The relationship is very contrary to the initial assumption that it is as if the deeper integration, foreign companies investing in the inland, led to attracting labor not only urban people but also the rural people and somewhat bring income to employees and reduce the difference between the two urban-rural areas. The result is quite true in Vietnam in recent years, most FDI is concentrated in the regions, the province has good infrastructure conditions, and invested heavily in the field of industry, real estate. Edu3 has a positive relationship with the inequality of income with a statistical significance 
of $10 \%$. From the analyzed data, the high ratio of education leads to a higher level of inequality of income since the urban areas are home to well-educated people to live and work.

The estimated variables are applicable to the nationwide scale. However, to have a depth analysis of the inequality regarding the rural-urban income, the paper categorizes the intensity of integration into different groups and based on which recommendations of policy are given.

\section{Recommendation}

Although the paper has researched and identified the causes of the inequality of rural-urban income in Vietnam in the context of the international integration, there are still unanswered questions: "Why is the Government supporting a number of policies that are beneficial to urban residents where the population is only about $30 \%$, while the majority of rural residents $(70 \%)$ have not been paid adequate attention and support?". This question is also the limitation of the paper, therefore more efforts in research should be put in order to find out the answer to this question.

Thus, in order to reduce the inequality of rural-urban income in future, some recommendations can be taken as:

(i). Management of markets for farming products: Wellmanaged and exploited markets for farming products are important for peasants to the increased competitiveness of exported products.

(ii). Restructure of exported product items towards increasing quality: Focus on Research and Development in new high-quality and productive seeds; Apply new methods in production.

(iii). Job - Counseling for farmers: First of all, it is necessary to revitalize traditional working villages. The reason for that resides in the historical development of these kinds of villages since they own many proprietary competitive advantages; Secondly, networking and developing supporting services for agricultural activities in a range of credits, insurance, technical supplies, mechanics and equipment, construction, food processing...for local and foreign market's needs.

(iv). Offerings of preferential bank loans for the development of agriculture: Commercial banks are prioritized to offer preferential loans for agricultural sectors to meet the demands of production and development.

(v). Spreading the state-owned and private-owned investments into agricultural infrastructure: Investing in the infrastructure and supporting services enables the agriculture to further its productivity, market penetration, commercial issues and rural industrialization. It is clear that infrastructure development is considered as a crucial stage to increase farmers' income, and to alleviate poverty in rural areas.

\section{Conclusions}

The research analyzed the degree, orientation and causes to the inequality of rural-urban income in Vietnam over the past years, especially in the process of international integration. Concretely, by using the data set from the 2008-2016 survey of living standards as well as other macro-economic data, the dissertation has proved that there exists an inequality of rural-urban income in all relevant variables of the analyzed model such as variables of regions, education, professionals, ethics and etc. However, the differences are expressed in different levels and seem to have a downward trend since Vietnam officially became a full member of WTO that is well demonstrated by the gap of rural-urban income was significantly shortened in 2016 as opposed to 2008 at all observed variables.

Additionally, when quantifying the impacts of the international integration on the inequality of rural-urban income in Vietnam, the regression figures out interesting outcomes adequate to Vietnam's reality in that the larger the proportion of export to GDP, the lower the level of the inequality of rural-urban income. Meanwhile, a contrary story is true to FDI to GDP which is attributed to that foreign investment into Vietnam is mainly for urban areas whose infrastructure is much better than rural ones. There are also other factors influencing the inequality of income such as the number of households using the internet, or the level of education.

\section{References}

Araujo, M. C., Ferreira, F. H., Lanjouw, P., \& Lanjouw, P. (2008). Local inequality and project choice: Theory and evidence from Ecuador. Journal of Public Economics, 92(5-6), 10221046. https://doi.org/10.1016/j.jpubeco.2007.12.005.

Atif, S. M., Srivastav, M., Sauytbekova, M., \& Arachchige, U. K. (2012). Globalization and Income Inequality: A Panel Data Analysis of 68 Countries. EconStor, 1-14. http://hdl.handle.net/10419/65664.

Barro, R. J. (2000). Inequality and Growth in a Panel of Countries. Journal of Economic Growth, 5(1), 5-32. Available at: https://scholar.harvard.edu/files/barro/files/p_inequalitygrw.pd f.

Blinder, A. S. (1973). Wage Discrimination: Reduced Form and Structural Estimates. Journal of Human Resources, 8(4), 436455. DOI: $10.2307 / 144855$.

Bukhari, M., \& Munir, K. (2016). Impact of Globalization on Income Inequality in Selected Asian Countries. Munich Personal RePEc Archive, 1-31. Retrieved from 
https://mpra.ub.uni-muenchen.de/74248/.

Ceddia, M. G. (2019). The impact of income, land, and wealth inequality on agricultural expansion in Latin America. PNAS, 116(7), 2527-2532. https://doi.org/10.1073/pnas.1814894116.

Central Institude for Economic Management. (2010). Impact of international economic integration on the economy after three years of Vietnam's accession to the WTO. Mutrap III project, Hanoi, Vietnam.

Communist Party of Vietnam. (2011). Document of the 11th National Congress. Hanoi, Vietnam: National Political Publishing House.

Communist Party of Vietnam. (2016). Document of the 12th National Delegation Congress. Hanoi, Vietnam: National Political Publishing House.

Communist Party of Vietnam. (1987). Document of the Sixth National Congress. Hanoi, Vietnam: Truth Publishing House.

Estrada, M. S. (2008). The role of institutions in the economic change of Mexico. Developmental Problems, 39(154), 37-59. Retrieved from http://www.scielo.org.mx/scielo.php?script= sci arttext\&pid=S0301-70362008000300003.

Forbes, K. J. (2000). A Reassessment of the Relationship between Inequality and Growth. American Economic Review, 90(4), 869-887. DOI: $10.1257 /$ aer.90.4.869.

General Department of Vietnam Customs. (2017). The situation of goods import and export of Vietnam in December and 12 months of 2016. Retrieved December 10, 2019, from https://www.customs.gov.vn/Lists/ThongKeHaiQuan/ViewDe tails.aspx?ID=1038\&Category=Phân\%20t\%C3\%ADch\%20đị nh\%20kỳ\&Group=Phân\%20t\%C3\%ADch

General Statistics Office. (2017). Socio-economic situation in 2016. Retrieved December 10, 2019, from https://www.gso.gov.vn/default.aspx?tabid=621\&ItemID=161 74

General Statistics Office. (2016). Result of the Viet Nam household living standards survey 2016. Hanoi, Vietnam: Statistical Publishing House.

General Statistics Office. (2018). Statistical summary book of Vietnam. Hanoi, Vietnam: Statistical Publishing House.

Goesling, B., \& Baker, D. P. (2008). Three faces of international inequality. Research in Social Stratification and Mobility, 26(2), 183-198. DOI: 10.1016/j.rssm.2007.11.001.

Joshi, R. (2018). Assessing the Impact of Income Inequality on Economic Growth: For a Cross Section of Indian States. The Indian Economic Journal, 65(1-4), 1-26. https://doi.org/10.1177/0019466217727811.

Kuznets, S. (1955). Economic Growth and Income Inequality. American Economic Review, 45(1), 1-28. https://www.jstor.org/stable/1811581.

Le, N. H., Duy, L. V., \& Ngoc, B. H. (2019). Effects of Foreign Direct Investment and Human Capital on Labour Productivity: Evidence from. Journal of Asian Finance, Economics and Business, 6(3), 123-130. https://doi.org/10.13106/jafeb.2019.vol6.no3.123.

Leamer, E. E. $(1995,2)$. The Heckscher-Ohlin Model in theory and practice. Retrieved from ///Users/anhcongtuan/Desktop/HeckscherOhlin\%20Model.pdf

Lee, J. W., \& Brahmasrene, T. (2016). Tourism effects on the environment and economic sustainability of sub-Saharan
Africa. International Journal of Sustainable Development \& World Ecology, 23(3), 221-232. https://doi.org/10.1080/13504509.2015.1114976.

Mabugu, R., \& Chitiga, M. (2007). South Africa trade liberalization and poverty in a dynamic microsimulation CGE model. Journal University of Pretoria, 18, 1-43. Retrieved from https://www.up.ac.za/media/shared/61/WP/wp_2007_18 .zp39499.pdf.

Majumdar, S., \& Partridge, M. D. (2009). Impact of Economic Growth on Income Inequality: A Regional Perspective. Agricultural and Applied Economics Association (pp. 1-12). Milwaukee, Wisconsin, AAEA and ACCI Joint Annual Meeting. DOI:10.22004/ag.econ.49270.

Ministry of Labor - Invalids and Social Affairs. (2018). Multidimensional poverty report in Vietnam: Reduce poverty in all dimensions to ensure a quality life for everyone. Hanoi, Vietnam: United Nations Development Program-UNDP.

Mundle, S., \& Arkadie, B. V. (1997). The rural-urban transition in Vietnam: some selected issues. Manilla, the Philippines: ADB.

Mustafa Mohamed, A. M. (2019). Contribution of Tourism and Foreign Direct Investment to Gross Domestic Product: Econometric Analysis in the Case of Sri Lanka. Journal of Asian Finance, Economics and Business, 6(4), 109-114. https://doi.org/10.13106/jafeb.2019.vol6.no4.109.

Nantharath, P., \& Kang, E. (2019). The Effects of Foreign Direct Investment and Economic Absorptive Capabilities on the Economic Growth of the Lao People's Democratic Republic. Journal of Asian Finance, Economics and Business, 6(3), 151-162. https://doi.org/10.13106/jafeb.2019.vol6.no3.151.

Neary, P. J. (2004). The Stolper-Samuelson theorem. London, UK: Centre for Economic Policy Research.

Nguyen, M. T. (2009). Using mathematical model to study the impact of international integration on household income inequality in Vietnam. Hanoi, Vietnam: Nationnal Economics University Publishing House.

Nguyen, T. M. (2011). Impact of WTO accession on income distribution among household groups in Vietnam. Journal of Economics and Development, 168, 52-61.

Ningsih, C., \& Choi, Y.-J. (2018). An Effect of Internet Penetration on Income Inequality in Southeast Asian Countries. Beyond the boundaries: Challenges for business, policy and society (pp. 1-20). Paper presented at the 22nd Biennial Conference of the International Telecommunications, Society. Seoul, Korea. http://hdl.handle.net/10419/190399.

Nurlanova, N. K., Satybaldin, A. A., Bekturganova, M. A., \& Kireyeva, A. A. (2018). Spatial Distribution of Economic Growth and Inequality: Kazakhstan's Experience. Journal of Asian Finance, Economics and Business, 5(3), 169-178. http://doi.org/10.13106/jafeb.2018.vol5.no3.169.

Oaxaca, R. (1973). Male-Female Wage Differentials in Urban Labor Markets. International Economic Review, 14(3), 693709. DOI: $10.2307 / 2525981$.

Panizza, U. (2002). Income Inequality and Economic Growth: Evidence from American Data. Journal of Economic Growth, 7(25), 25-41. https://www.jstor.org/stable/40216052.

Perry, G., \& Olarreaga, M. (2006). Trade Liberalization, Inequality and Poverty Reduction in Latin America. San Petersburg: Worldbank. Retrieved from 
http://siteresources.worldbank.org/INTDECABC2006/Resour ces/GuillermoPerry.PDF

Roland-Holst, D., \& Tarp, F. (2003). Globalization, Economic Reform, and Structural Price Transmission: SAM Decomposition Techniques with an empirical application to Vietnam. Munich: MPRA Paper 29367, University Library of Munich, Germany.

Stolper, W. F., \& Samuelson, P. A. (1941). Protection and Real Wages. The Review of Economic Studies, 9(1), 58-73. https://doi.org/10.2307/2967638.

Subramanian, S. (1997). Measurement of Inequality and Poverty. Oxford, UK: Oxford University Press.

Tian, X., Wang, B., \& Dayanandan, A. (2008). The Impact of Economic Globalization on Income Distribution: Empirical Evidence in China. Economics Bulletin, 4(35), 1-8. Retrieved from

http:/www.accessecon.com/pubs/EB/2008/Volume4/EB-
08D30006A.pdf.

Trinh, L. D., \& Nguyen, M. X. (2008). Social impact of international integration and WTO accession in Vietnam. (pp. 4-23). Paper presented at Danang, Vietnam, Economic and Financial Forum, Seventh Session. Retrieved December 10, 2019 from: http://tailieu.vn/xem-tai-lieu/tac-dong-xa-hoicua-hoi-nhap-kinh-te-quoc-te-va-gia-nhap-wto-o-viet-nam. 166283.html.

Wei, S.-J., \& Wu, Y. (2001). Globalization and Inequality: Evidence from Within China. National Bureau of Economic Research (NBER Working Paper No. 8611). DOI: $10.3386 / \mathrm{w} 8611$.

Wu, J.-X., \& He, L.-Y. (2018). Urban-rural gap and poverty traps in China: A prefecture level analysis. Applied Economics, 50(30), 3300-3314.

https://doi.org/10.1080/00036846.2017.1420890. 